高齢者の安全性からみた浴室床の水勾配，すべりの評価に関する研究 歩行の場合の評価指標の提示

\title{
STUDY ON EVALUATION OF PITCH OF WASH AND SLIPPERINESS ON BATHROOM FLOORS FROM A VIEWPOINT OF SAFETY OF THE AGED
}

Presentation of evaluation index at walking

\author{
横山＼cjkstart裕*1, 稲垣太郎*2, 高橋宏樹*3, 小野英哲*4 \\ Yutaka YOKOYAMA, Taro INAGAKI, Hiroki TAKAHASHI \\ and Hidenori ONO
}

\begin{abstract}
This paper presents the evaluation index of pitch of wash and slipperiness on bathroom floors from a viewpoint of safety of the aged. At first, we carried out the sensory test using sample floors and young panels wearing an outfitting equipment. The equipment was developed for the young to simulate geriatric gait. After the sensory test, we constructed the psychological scale. Then, we measured C.S.R.B of the sample floors using O-Y.Pull Slip Meter. C.S.R.B was the quantitative value corresponding to slipperiness. Secondly, based on the relationship between the psychological scale and pitch and C.S.R.B, the evaluation index was obtained.
\end{abstract}

Keywords : bathroom floor, pitch of wash, slipperiness, the aged, safety, evaluation index 浴室床, 水勾配,すべり，高齢者，安全性，評価指標

1. はじめに

既報1では、浴室床の水勾配,すべりの評価指標を提示する背景,意義 などを述べるとともに、比較的年輸の低い居住者層(主に20歳代,以降 高齢者との比較の意味で“若歯者”之記す)を対象に、歩行時の安全性か らみた水勾配,すべりの評価指標を提示した。

一方近年、高齢者の日常の安全性に関する資料の早急な蓄積が必要 とされている。しかし高齢者の水勾配,すべりの評価は、動作の形態が 異なることなどから、若齢者とは異なる可能性がある。

本報は、高齢者の安全性からみた水勾配,すべりの評価指摽を提示し た経過,結果を述べるものである。

なお本報は、日本建築学会大会での発表22に、さらに検討を加えた ものである。

\section{2. 本研究の目的,範囲}

本研究は、高齢者の安全性からみた浴室床の水勾配,すべりの評価指 標を提示し、水勾配,すべりの許容範囲策定などの資料とすることを目 的とする。評価の観点は、すべりやすさおよび足元の不安定さとす る。なお水勾配,すべりの許容範囲の策定および浴室床の具体的な評

価、安全な浴室床の開発などは範囲外とする。

対象とする動作は、浴室で一般的な種々の動作の基本となるいくつ かの動作のうち、安全性の観点から重要な動作のひとつである歩行と する。また高齢化による歩行動作の形態の変化は、個人差はあるもの
のおおむね60歳代から表れはじめ70歳代で明確になる3)ことから、本 研究では高齢者を60歳代以上と定義する。なお浴槽に出入りする動作 などより危険な動作を対象とした場合の評価指標については、本研究 結果と若齢者を対象に歩行および浴槽出入の場合の評価指標を提示し た筆者らの研究1),4結果から類推することによる、今後の課題とする。

\section{3. 既往の研究}

浴室床の水勾配,すべりの評価を直接対象とした研究例は、若儌者を 対象とした筆者らの研究 ${ }^{1) 4}$ (4) 以外に見あたらない。このうち步行を対象 とした既報1の結果は、本研究結果と逐次比較する。

一方、高齢者の安全性からみた居室床のすべりの評価に関する研究 例はいくつか報告されており、このうちすべりの評価とすべり抵抗の

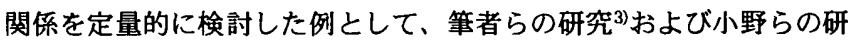

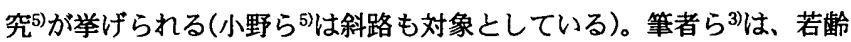
者に高齢者と近似したメカニズムの歩行をさせることができる“歩行 メカニズム高齡化装具”を開発し、装具装着時と末装着時の若齢者の 評価の比較から、歩行メカニズムの高龄化によるすべりの評価の相対 的変化を推定している。また小野ら5)は、実際に高齢者を検查員とし て用いて官能検查を実施する機会を得、高齢者の評価とすべり抵抗の 関係からすべりの評価指標,評価方法を提示している。さらに小野ら5) は、高歯者と中跉者(若齢者と高齢者の間の年齢層)のすべりの評価は 極めて高い近似性を有すること、前述の歩行メカニズム高秢化装具を

\footnotetext{
*1 東京工業大学工学部建築学科 助教授. 工博 (当時 名古屋工業大学工学部社会開発工学科)

*2 村田機械侏) (当時 名古屋工業大学大学院) - 修士 (工学)

*3 東京工業大学工学部建築学科 助手・体育修

Assoc. Prof., Dept. of Architecture and Building Eng., Faculty of Eng., Tokyo Institute of Technology, Dr. Eng

Murata Machinery, M. Eng.

Research Assoc., Dept. of Architecture and Building Eng., Faculty of Eng., Tokyo Institute of Technology, M. Phys. Educ.

*4 東京工業大学工学部建築学科 教授・工博

Prof., Dept. of Architecture and Building Eng., Faculty of Eng., Tokyo Institute of Technology, Dr. Eng.
} 
装着した若齢者の評価は高跉者の評価をほほ再現していることを、明 らかにしている。本研究では、これらの研究結果を、高齢者の評価の 定量化の際参考にする。

\section{4. 本研究の研究方法および手順}

高齢者の安全性からみた評価指徱を提示するためには、高齢者の評 価を定量化する必要がある。小野ら淿は、高齢者のすべりの評価を生 理反応あるいは動作の変化などに基づいて定量化することを試みた が、いずれも明確な傾向は得られず、現段階では心理反応に基づいて 定量化するのが最も有効な方法と結論づけている。すなわち高齢者を 検查員として用いて官能検査を実施するのが理想的といえる。しかし 現実的には、多数の高齢者の確保、検査中の安全性の確保などきわめ て多くの因難をともなうため、検查を実施する機会が得られるのは稀 である。一方 3 . で述べた通り、小野らの研究5)の結果、高齢者の評 価は中齢者または歩行メカニズム高齢化装具を装着した若齢者の評価 で代替できることが明らかになっている。本研究では、若齢者の検査 員の確保が比較的容易であったことから、歩行メカニズム高齢化装具 を装着した若齢者(以降“疑似高齢者”と記す)の評価で高龄者の評価を 代替することとした。

つぎに本研究の手順を以下に示す。

1)勾配の向き,大きさおよびすべり抵抗を種々変化させられる模擬床を 製作する。

2)1)で製作した模擬床を用い、勾配の向きを種々変化させられる条件 で官能検查を実施し、最も危険な勾配の向きを求める。

3)1)で製作した模凝床を用い、勾配の大きさとすべり抵抗の組合せを 種々変化させられる条件で官能検査を実施し、すべりやすさ,足元の 不安定さに関する心理学的尺度を樌成する。模擬床の勾配の向き は、2)で求めた最も危険な向きとする。

4)3)で堆成した心理学的尺度と勾配の大きさ,すべり抵抗の関係を、水 勾配,すべりの評価指標として提示する。

以上であるが、すべり抵抗は、既報1)と同様、小野らが開発しJIS A 5705に規定されたすべり試験機O-Y·PSMで測定されるC.S.R・B B 表示することとした。

\section{5. 歩行メカニズム高齢化装具の概要}

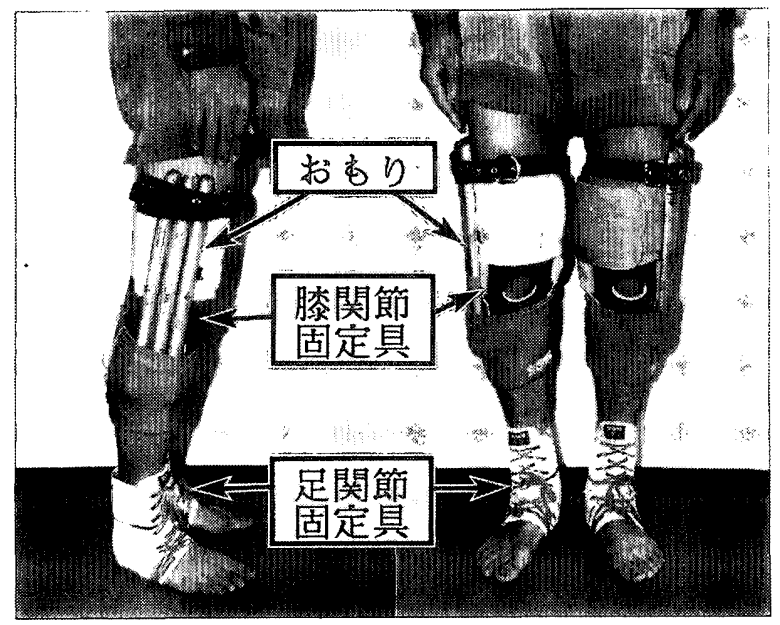

写真 -1 歩行メカニズム高齫化装具の概要
马真ー1に、筆者らが開発した歩行メカニズム高齢化装具の概要を 示す。本装具は凌関節固定具,足関節固定具,おもりなどからなる。

腅関節固定具,足関節固定具は、関節を動きにくくすることにより、 高齢化による関節の硬化および関節を動かすのに必要な筋力の低下の 影響を具現するものである。さらにこれらの固定具により、平衡保持 能力の低下の影響も具現できる。なお足関節固定具は、歩行中の主要 な足裹接床部位を避け、土踏まずの部分に装着する形式としている。

またおもりは、重量 $1 \mathrm{kgf}$ の棒状の鈶を各足 3 本ずつゴムバンドで大 腿に装着することにより負荷を課し、大腿直筋の筋力の低下の影響を 具現するものである。

本装具を装着した若齢者の歩行メカニズムは60～70歳代以上まで高 歯化することを、既往の研究 ${ }^{3)}$ で確認している。また、本装具は若歯 者の平衡感覚まで高齢化するものではないが、本装具を装着した若跉 者の評価は高齢者の評価をほほ再現していることが明らかになってい る5ことから、平衡感覚の違いは評価に大きく影響しないものと想定 できる。なお本装具の詳細および開発経過などは、既往の研究3)で述 ベている。

\section{6. 最も危険な勾配方向の究明}

\section{1 本節の目的}

勾配,すべりの評価は、勾配の向きと足の向きの関倸(以降“勾配方 向”之記す)により異なることが予想される。本研究では、既報”之同 様、勾配の向きに対して最も危険な向きに足が接床する場合を対象に 評価指標を提示することとした。これは、実際の浴室床では足の向き を特定できない場合が一般的であること、安全性の観点からの評価の 場合実際に起こり得る範囲内で最も危険な状況を対象とする必要があ るといえることによる。

本節の目的は、勾配方向とすべりやすさ,足元の不安定さの関係を検 討し、最も危険な勾配方向を究明することにある。

\section{2 模擬床の概要}

図ー1に、本研究に用いた模擬床の概要を示す。

本模擬床は、既報1)で製作したもので、勾配の向きおよび大きさを 勾配調整用スペーサにより種々変化させられる可動部と、可動部を歩 き抜ける前後に数歩歩行するための固定部からなる。またすべり抵抗 は、表面に貼付する仕上げ材(以降“表面材”と記す)により種々変化さ せることができる。模擬床の製作にあたっては、官能検查時に検查員 が所定の動作をするのに十分な面樻を確保することなどに留意した。 6.3 勾配方向に関する官能検查

6.3.1 官能検查要領

最も危険な勾配方向を求めるための官能検査を、表ー1に示す要領

平面図

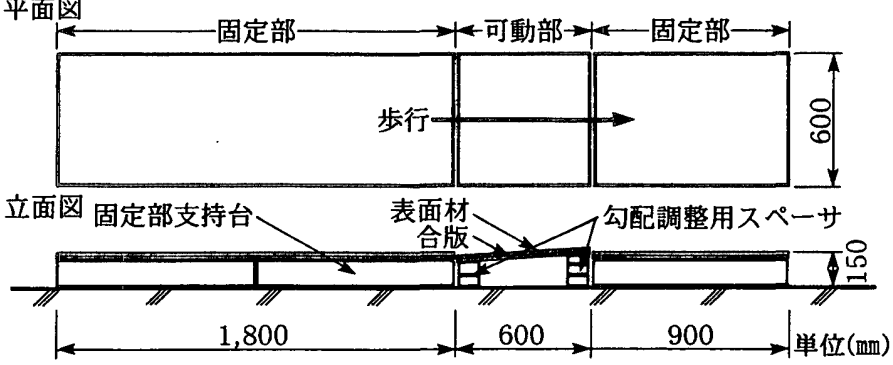

図 -1 模擬床の概要 
で実施した。以下に主な事項について説明を加える。 6.3.1.1 検查項目

検査員に、すべりやすさ,足元の不安定さの観点から最も危険と感じ るのはどの勾配方向かを尋ね、回答を求めた(複数回答可)。

また検査後、着地と踏切のどちらの時点で主に危険を感じたかを尋 ね、表一 1 に示す(1) (3)の選択肢の中から回答を求めるアンケートを 行った。

\subsubsection{2 検査試料}

表一1に示す前下り，後下り，内下り，外下りの 4 種の勾配方向を検査試 料として設定した。検査試料の設定にあたっては、検査員に疲労,倦㤐 を感じさせないよう、検查試料数を必要最小限にとどめることに留意 した。

\subsubsection{3 動作}

動作は、模擬床の一方の固定部上を数歩歩行した後、勾配が設けら れた可動部上に一歩着地し、もう一方の固定部上に歩き抜ける動作と した。動作の速さ，激しさなどは検査員の自由としたが、無理に速く， 激しく動作しようとしないよう教示した。これは、装具による歩行メ カニズムの高制化の程度が低下する可能性がある゙ことによる。

\subsubsection{4 表面材および履物}

最も危険な勾配方向はすべり抵抗により変化する可能性があると思 われたことから、実在する浴室床の範囲内で最もすべりやすい部類の 床と同等のすべり抵抗を具現できる表面材(1)、および最もすべりにく い部類の床と同等のすべり抵抗を具現できる表面材(2)の、2種の表面 材を選定した。

また履物は、足裏のすべり性状を一定に保ちやすくかつできるだけ 素足に近似した装着感を有する薄手くつ下とし、表面材と履物の間に 媒介物が介在しない状態で検査を行うこととした。

ここで本検查を浴室で一般的な素足でかつ液状媒介物が介在する状 態で行わないこととしたのは、勾配が設けられた模擬床では検查中液 状媒介物の状態を一定に保つのが非常に困難であること、検査員の判 断に与えるすべり抵抗の影響が把握できればそのすべり抵抗がどのよ うな表面材,履物,媒介物の組合せで具現されたものであっても本検査 の目的は達成されることによる。表面材(1),(2)と薄手くつ下の組合せで のC.S.R·Bは、表ー1に示す通りであ る1)。

\subsubsection{5 勾配の大きさ}

最も危険な勾配方向は勾配の大きさ により大きく変化しないと思われたこ とから、勾配方向による差がより明確 に感じられるよう、勾配の大きさは検 査員の安全が確保できる範囲内ででき るだけ大きくすることとし、表ー1に 示す通りとした。

\subsubsection{6 検查員}

既報1より、すべりやすさ,足元の不 安定さの判断に検查員の性による差は ほとんど生じないものとみなし、若齢 者男子7名(20歳代)を選定した。検査 員には、歩行メカニズム高齢化装具を 装着した。
表 -1 勾配方向に関する官能検查要領

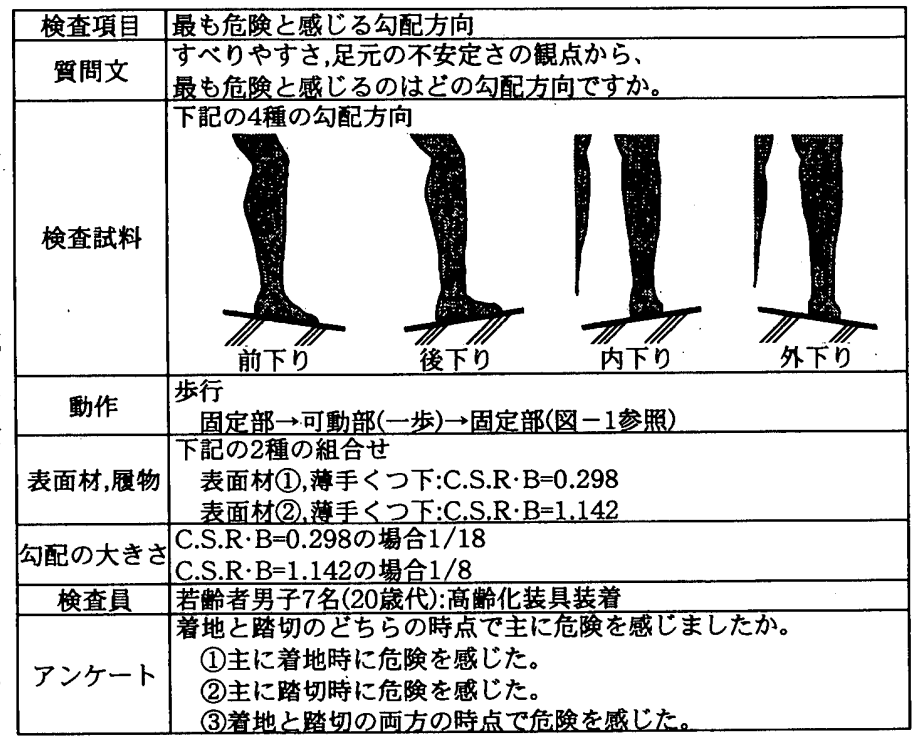

\subsection{2 官能検查経過,結果}

6.3.1で述べた条件の他に、すべりやすさ, 足元の不安定さ以外の要 因は判断にいれないこと、浴室でかつ勾配が設けられていることを認 知していない場合を想定すること、疲れたらいつでも自由に休めるこ となどを条件に、官能検査を実施した。

検查は、模擬床の可動部中央に自然に着地できるよう歩幅の調整を かねた練習を十分行った後実施した。はじめに4種の勾配方向でそれ ぞれ数回ずつ動作した後、検査員の要求に応じて勾配方向を逐次变化 させ、徐々に最も危険な勾配方向を絞り込む方法で行った。検査員 1 名が最も危険な勾配方向を決定するのに要した時間は、おおむね 15 分 程度であった。

図ー2の I に勾配方向に関する検查結果を、また II に危険を感じる 時点に関するアンケート結果を示す。なお検查員が複数回答(例:2個) した場合には、回答数を補正(例:1/2)した。 6.4 最も危険な勾配方向の究明

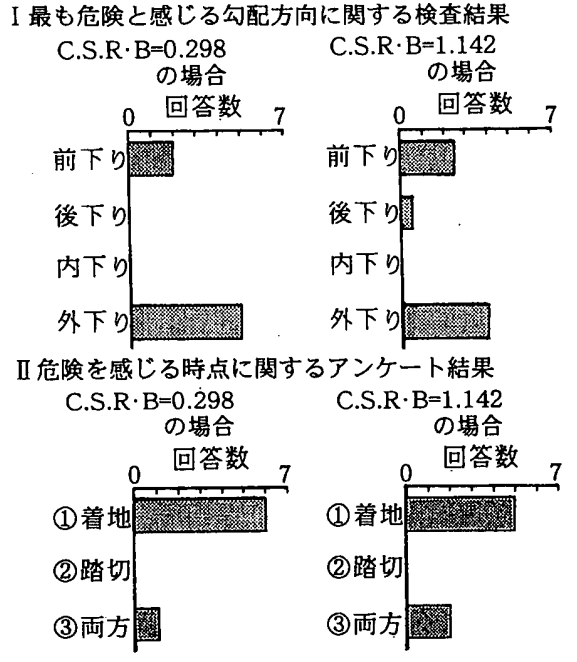

疑似高齢者の結果

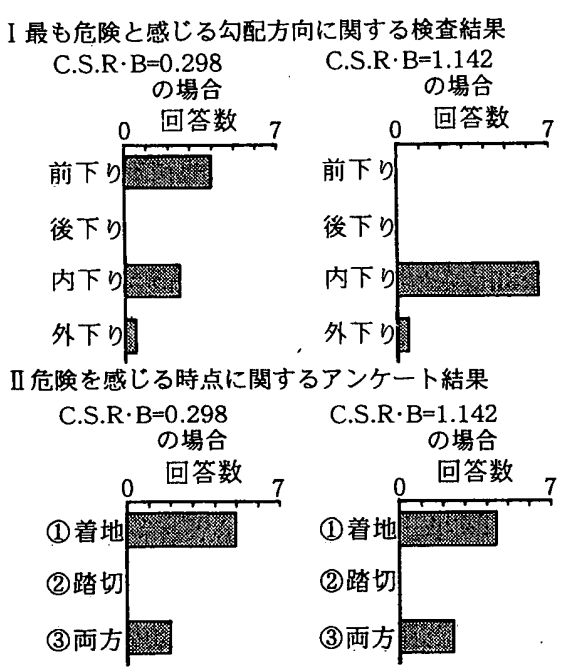

若舲者の結果
図-2 勾配方向に関する官能検查結果 図-3 既報 ${ }^{11}$ の勾配方向に関する官能検查結果 
図ー3に、若齡者を対象とした既報1)の結果を図-2 と比較して示 す。

図-2の II と図-3の II から、疑似高齢者の場合も若齢者と同様、い ずれのC.S.R・Bでも選択肢(1)の回答数が最も多く、逆に(2)の回答数は 0となっており、すべり抵抗のいかんにかかわらず主に着地時に危険 を感じていることがわかる。

つぎに図-2の I と図-3の I から、以下の事項が考察できる。

若齢者の場合、主に足元の不安定さが判断に大きく影響すると思わ れる非常にすべりにくいC.S.R·B=1.142では、内下りの回答数が全回 答数の $90 \%$ 以上を占めている。この理由のひとつとして、歩行中片足 で接床している状態での身体の重心が接床している足の中心より内側 にあるため、足元が不安定になりやすいことが考えられる。またすべ りやすさと足元の不安定さの両方が判断に影響すると思われる非常に すべりやすいC.S.R·B=0.298では、前下りの回答数が最も多く、続い て内下りが多くなっている。前下りの回答数が多い理由のひとつとし て、着地時に人間が床に与える水平荷重の方向が下り勾配の方向とほ ほ一致するため、すべりを制御しにくいことが考えられる。以上よ り、若歯者の場合、すべりやすさの観点からは前下り、足元の不安定 さの観点からは内下りが、それぞれ最も危険な勾配方向とみなすこと ができる。

一方疑似高齢者の場合、若踚者と異なり、いずれのC.S.R·Bでも外 下りの回答数が最も多く、続いて前下りが多くなっている。この理由 のひとつとして、歩行メカニズムが高齢化するにしたがって歩幅が減 少する一方歩隔(左右の足の着地位置の間隔)が増加し、足の運びが前 方向から前外方向に変化するとともに、一歩ずつ足を運ぶ方向に身体 を傾斜させながらゆっくりと前進する形態の歩行となる゙ここど考え られる。すなわち外下り,前下りの場合、着地時に人間が床に与える水 平荷重の方向や身体の傾斜による重心の移動方向が下り勾配の方向と 近似するため、すべりを制御しにくくかつ足元が不安定になりやすい ものと思われる。

以上の考察より、疑似高跉者の場合、最も危険な勾配方向はおおむ ね外下りから前下りにかけての範围であることが究明できたといえ る。本研究では、この範囲内の代表的な勾配方向として外下り,前下り の2種を対象に勾配の大きさ,すべり抵抗とすべりやすさ,足元の不安定 さの関係を求め、両者の関係が求められた段階で 2 種の勾配方向によ る差について検討することとした。

7. 水勾配,すべりの評価指標の提示

7.1 本節の目的

本節の目的は、勾配の大きさ,すべり抵抗とすべりやすさ,足元の不 安定さの関係を検討し、水勾配,すべりの評価指標を提示することにあ る。

7.2 勾配,すべりの評価に関する心理学的尺度の構成

\section{2 .1 心理学的尺度構成のための官能検查要領}

心理学的尺度構成のための官能検查を、表一2に示す要領で実施し た。以下に主な事項について説明を加える。

7.2.1.1 構成する尺度および尺度構成手法

構成する尺度は、すべりやすさ,足元の不安定さの観点からどの程度 安全,危険かを表す“勾配，すべり評価尺度”とした。尺度構成手法は、 既報”と同様、系列範ちゅう法”とした。判断範ちゅうは表ー2に示す
表 -2 勾配,すべりの評価に関する官能検査要領

\begin{tabular}{|c|c|}
\hline 構成する尺度 & 勾配,すべり評価尺度 \\
\hline 尺度構成手法 & 系列範ちゅう法 \\
\hline |判断範ちゅう & $\begin{array}{l}\text { この浴室床は、 } \\
\text { すべりやすさ,足元の不安定さの観点から、 } \\
\text { (7)非常に安全である。 } \\
\text { (6)かなり安全である。 } \\
\text { (5)やや安全である。 } \\
\text { (4)どちらともいえない。 } \\
\text { (3)やや危険である。 } \\
\text { (2)かなり危険である。 } \\
\text { (1)非常に危険である。 }\end{array}$ \\
\hline 検査試料 & \begin{tabular}{|l} 
勾配の大きさ 6 種 $\times$ 表面材 5 種(履物:薄手くつ下) \\
-勾配の大きさ \\
$0,1 / 50,1 / 25,1 / 18,1 / 12,1 / 8$ \\
・表面材と薄手くつ下の組合せのC.S.R.B \\
表面材 1 ,薄手くつ下: 0.298 \\
表面材 2 ,薄手くつ下:0.722 \\
表面材 3 ,薄手くつ下: 0.920 \\
表面材 4 ,薄手くつ下: 1.042 \\
表面材 5 ,薄手くつ下: 1.142 \\
ただし検查員の安全性確保の観点から \\
C.S.R.B . 0.298 場合 $1 / 12,1 / 8$ 除外 \\
\end{tabular} \\
\hline 動作 & $\begin{array}{l}\text { 歩行 } \\
\quad \text { 固定部 } \rightarrow \text { 可動部 }(\text { 一歩) } \rightarrow \text { 固定部(図 }-1 \text { 参照) }\end{array}$ \\
\hline 勾配方向 & 前下り,外下りの2種 \\
\hline 検查自 & 高齢化 \\
\hline
\end{tabular}

通りである。なお系列範ちゅう法では、尺度構成の過程で、検查に用 いた判断範ちゅうの尺度上の位置(相互の間隔も意味を持つ)が算出さ れることを付け加える(尺度構成手法の詳細は文献》を参照されたい)。

\subsubsection{2 検查試料}

表ー2に示す0〜1/8の6種の勾配と5種の表面材 1 ～5の組合せを検査 試料として設定した。ただし表ー2に示す通り、一部の組合せは検査 員の安全性確保の観点から検查試料より除外した。

また6.3.1.4で述べたと同様の理由から、履物は薄手くつ下とし、表 面材と履物の間に媒介物が介在しない状態で検查を行うこととした。 表面材 $1 \sim 5$ と薄手くつ下の組合せでのC.S.R·Bは、表-2に示す通り である1。

検查試料の設定にあたっては、以下の点に留意した。

・浴室床として実在する、もしくは今後具現する可能性があると思わ れる勾配の大きさ,すべり抵抗の範囲を十分包含する検査試料群とす る。

・検查期間中すべり抵抗が変化しない検査試料とする。

・検査員に疲労,倦急を感じさせない検查試料数とする。

\subsubsection{3 動作}

6.3.1.3で述べたと同様とした。

7.2.1.4 勾配方向

6.4で述べた通り、前下り，外下りの 2 種とした。

\subsubsection{5 検查貝}

6.3.1.6で述べた理由から、若歯者男子10名(20歳代)を選定した。検 查員には、歩行メカニズム高歯化装具を装着した。

7.2 .2 官能検査経過,結果および心理学的尺度の構成

7.2.1で述べた条件の他に、6.3.2で述べたと同様の条件で官能検査 を実施し、基礎テータを得た。検查員 1 名がひとつの検查試料に対す る判断に要した時間は、1〜3分程度であった。 
表 -3 分散分析結果

\begin{tabular}{|c|c|c|}
\hline & 分散比 & 寄与率 \\
\hline 主効果 & $48.2842^{*}$ & $76.10 \%$ \\
\hline 個人差 & $26.9414^{*}$ & $7.52 \%$ \\
\hline
\end{tabular}

※:危険率 $1 \%$ 以内で有意

官能検查の結果得られた基礎テータの分散分析結果を表 -3に示す。主効果の分散比が高度に有意でありかつ寄与 率も大きいことから、検查試料の刺激に十分な差があるこ と、本検查自体が有効であることがわかる。また個人差の 分散比も有意となっているが、分散比,寄与率ともに主効 果と比較して小さいことから、構成される尺度は個人差が 内包されるものの十分有効とみなすことができる。

以上から、官能検查の結果得られた基礎デー夕を用い、 尺度構成理論》にしたがって勾配,すべり評価尺度を構成し た。

7.3 心理学的尺度と勾配の大きさ,すべり抵抗の関係の検討

図一4に、勾配,すべり評価尺度と勾配の大きさの関係を 勾配方向ごとに示す。耐者はなめらかに対応しており、図 に示すごとくC.S.R·Bごとに対応の中心傾向を示す“対応 曲線”を得ることができる。なお図中の(1)〜7)の破線は、 表ー2に示した判断範ちゅうの評価尺度上の位置を表すも のである(7.2.1.1参照)。

図から、いずれのC.S.R・Bでも勾配が大きくなるほど評 価が低下すること、特にすべり抵抗が十分確保されている と思われるC.S.R・B $=1.0$ 程度以上の床でも勾配が大きくな るにしたがって足元の不安定さの影響で評価が低下するこ とがわかる。こ の傾向は、若嘢 者を対象とした 既報1)と一致す る。

また図一 5 に、勾配、すべ り評価尺度と C.S.R・Bの関係 を勾配方向ごと に示す。両者は なめらかに対応 しており、図に 示すごとく勾配 の大きさごとに 対応曲線を得る ことができる。

図から、全体的にみて、いずれの勾配の大きさでもC.S.R・Bが大き くなるほど評価が高くなる傾向がわかる。この傾向は、若㱓者を対象 とした既報1と一致する。しかし詳細にみると、若鰙者と異なり、一 部の条件でC.S.R・B=1.142の評価が1.042の評価よりわずかに低下し ていることがわかる。この理由のひとつとして、歩行メカニズムの高 齢化により歩行形態がすり足気味になる3゙た、すべり抵抗が大きい

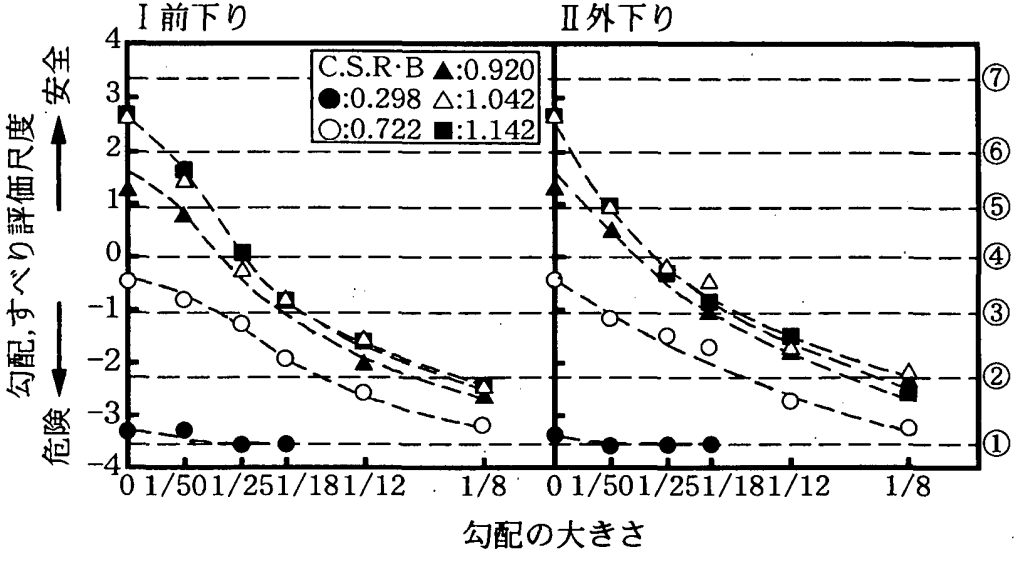

図-4＼cjkstart勾配,すべり評価尺度と勾配の大きさの関係

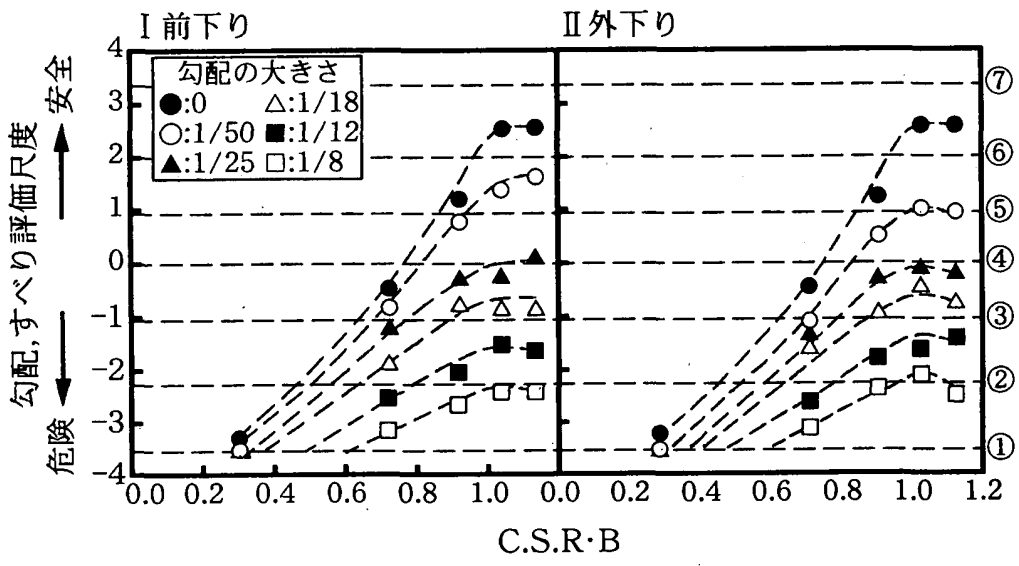

図-5＼cjkstart勾配,すべり評価尺度とC.S.R·Bの関係
II 勾配,すべり評価尺度と C.S.R.Bの関係

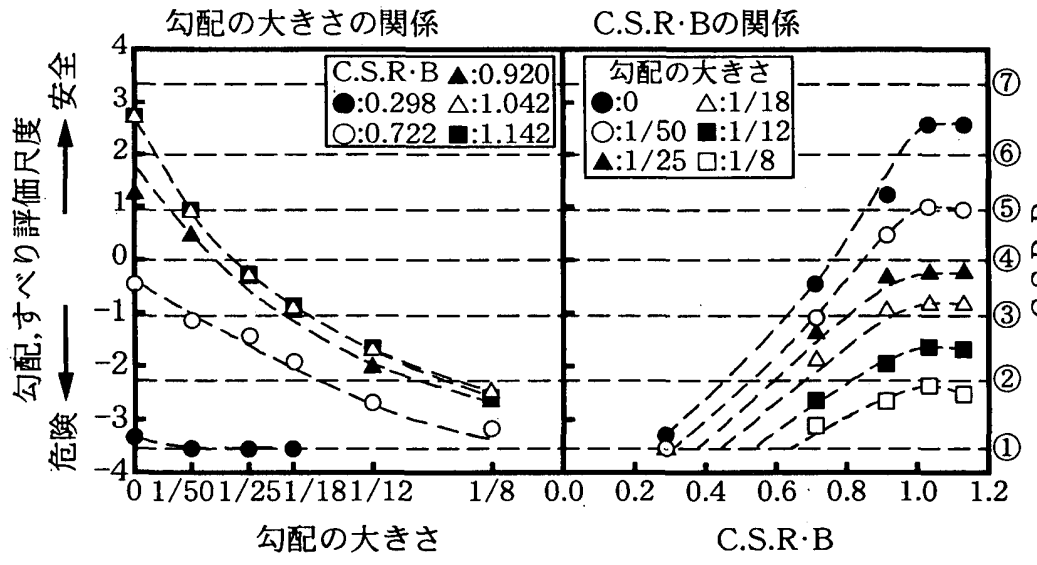

III勾配,すべり評価尺度と

勾配の大きさ,C.S.R・Bの関係

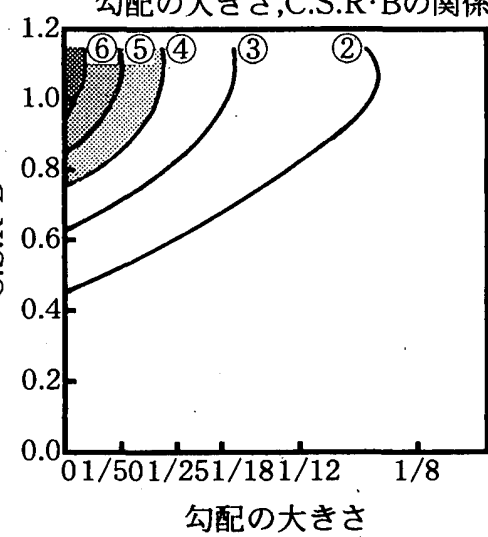

高齢者の評価指標

図－6＼cjkstart水勾配,すべりの評価指標

休では着地時につつかかりを生じやすいことが考えられる。なお住居

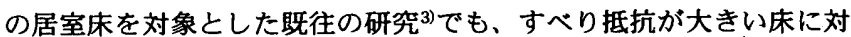
する疑似高齢者の評価は若路者よりやや危険となるとの結果が得られ ている。

さらに図ー4,5の I と II の比較から勾配方向による評価の差につい て考察すると、いずれの組合せでも前下りと外下りで評価に大きな差 
はないことがわかる。このことから、前下りか ら外下りにかけての範曲内の他の勾配方向での 評価も、前下り，外下りでの評価と大きく異なら ないものと想定できる。

7.4 水勾配,すべりの評価指標の提示

図-4,5から、勾配の大きさとC.S.R・Bの組合 せごとに前下り，外下りのうち危険と評価された 方の評価を抽出し、勾配の大きさ,C.S.R.Bとの 関係を示したのが図ー6の I , IIである。図ー6の I , II は、それぞれの組合せに対し勾配方向によ るわずかな差の範囲内でより危険と評価された 側の評価を与えるものであり、安全性からみた 水勾配，すべりの評価指標の基本として十分妥当 とみなすことができる。

また図ー6の I , II から(2) (6)の破線と対応. 曲線の関係を求 め、勾配の大き さ-C.S.R.B平 面上に表現した のが図-6のIII である。

さらに図ー6 から、例えば範 ちゅう(4)〜(6)を 許容基準之仮定 し、この基準よ り安全と評価さ れている(対応 曲線が安全側に

ある)勾配の大きさ,C.S.R・Bの範囲を安全性の観 点から許容される範囲の例(以降“許容範囲(例)” と記す)として求め、図一7に示した。

本研究では、高齢者の評価は疑似高䶕者の評 価で代替できることが明らかになっている゙こと より、疑似高齢者を用いて得られた図ー6,7を高 齢者の安全性からみた浴室床の水勾配,すべりの 評価指標として提示する。ただし図ー7に示した 許容範囲はあくまでも例であり、実際には状況 に応じて許容基準を策定し、図ー6から許容範囲 を求めるのが妥当といえる。

最後に、本研究で提示した評価指標を、既報1) で提示した若齢者の評価指標と比較する。図一

8,9 に既報1の結果を示す。図一 6,7 と図 $-8,9$ の比較から、以下の事項 が考察できる。

1)勾配0かつC.S.R・B=1.0程度以上の組合せの評価は、高齢者,若齡者 ともに範ちゅう(6)かなり安全である”より安全となる。

2)勾配の増加およびC.S.R・Bの低下による評価の低下度合い(図-6,8 の I , II の対応曲線の傾き)は、高齢者の方が若龄者より大きい。し
I 勾配の大きさの許容範囲(例)

\begin{tabular}{|c|c|}
\hline \begin{tabular}{|c|} 
勾配の大きさ \\
$01 / 501 / 251 / 181 / 12 \quad 1 / 8$ \\
\end{tabular} & C.S.R.B \\
\hline & 0.7 \\
\hline 8 & 0.8 \\
\hline 2 & 0.9 \\
\hline 2 & 1.0 \\
\hline 28 & 1.1 \\
\hline
\end{tabular}

II C.S.R·Bの許容範囲(例)

\begin{tabular}{|c|c|}
\hline C.S.R.B & 勾配の \\
\hline $\begin{array}{llllll}0.00 .2 & 0.4 & 0.6 & 0.8 & 1.0 & 1.2\end{array}$ & 大きさ \\
\hline 8 & 0 \\
\hline \% (1) & $1 / 50$ \\
\hline & $1 / 25$ \\
\hline & $1 / 18$ \\
\hline & $1 / 12$ \\
\hline
\end{tabular}

13範ちゅう6 “かなり安全である”を許容基準とした場合の許容範囲 :範ちゅう(5)“やや安全である”を許容基準とした場合の許容範囲 :範ちゅう(4)“どちらともいえない”を許容基準とした場合の許容範囲 高齢者の許容範囲(例)

図-7 水勾配,すべりの許容範囲(例)

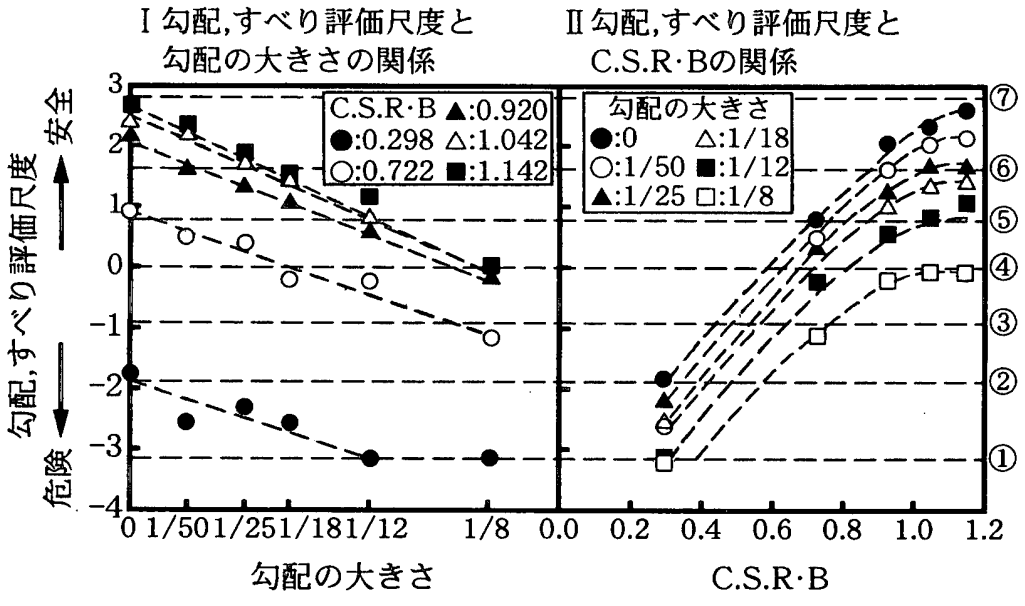

若齢者の評価指標
III勾配,すべり評価尺度と 勾配の大きさ,C.S.R·Bの関係

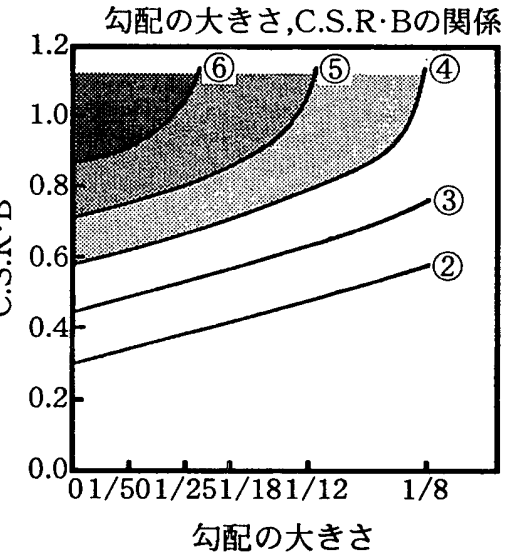

図一8 既報 ${ }^{1)}$ の水勾配,すべりの評価指標

I 勾配の大きさの許容範囲(例)

\begin{tabular}{|c|c|c|c|}
\hline 勾配の大きさ & $C C^{C} \mathrm{D}, \mathrm{R}$ & C.S.R.B & 勾配の \\
\hline $01 / 501 / 251 / 181 / 12 \quad 1 / 8$ & C.S.K. & $\begin{array}{llllll}0.000 .2 & 0.4 & 0.6 & 0.8 & 1.0 & 1.2 \\
\end{array}$ & 大きさ \\
\hline 28 & 0.7 & 18 & 0 \\
\hline (1) & 0.8 & 2 & $1 / 50$ \\
\hline (1) & 0.9 & $\overline{2}$ & $1 / 25$ \\
\hline (1) & 1.0 & ( & $1 / 18$ \\
\hline (1) & 1.1 & $\overline{\mathrm{Z}}$ & $1 / 12$ \\
\hline
\end{tabular}

:範ちゅう(6) “かなり安全である”を許容基準とした場合の許容範囲 :範ちゅう(5)“やや安全である”を許容基準とした場合の許容範讲

:範ちゅう(4)“どちらともいえない” を許容基準とした場合の許容範囲 若齢者の許容範囲(例)

図-9 既報 ${ }^{1)}$ の水勾配,すべりの許容範囲(例)

たがって、1)で述べた範囲を除き高齢者の評価は若路者より危険と なり、許容範囲(例)は小さい。

3)高齢者と若齢者の勾配の増加による評価の低下度合いの差(図-6の I と図-8の I の対応曲線の傾きの差)は、C.S.R·Bの低下による評 価の低下度合いの差(図-6の II と図-8の II の対応曲線の傾きの差) より大きい。すなわち高齢者の場合、若齢者と比較して、C.S.R·B 
より勾配の大きさが評価により大きく影響する。

8. おわりに

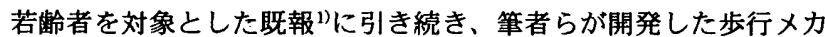
ニズム高秢化装具を用い、高齢者の安全性からみた浴室床の水勾配,す べりの評価指標を提示した経過,結果を述べた。また高舲者の評価指標 と既報1で提示した若齢者の評価指標の比較から、高齢者の評価は若 路者より危険となり許容範囲(例)は小さいこと、高歯者の場合若路者 と比較してC.S.R・Bより勾配の大きさが評価により大きく影響するこ となどを明らかにした。本研究結果は、高㱓者の日常の安全性確保の ための有効な資料となるものと考える。

謝辞

床材などを御提供いただいたメーカー各社の関係各位に謝意を表し ます。

\section{参考文献}

1)横山裕,小野英哲，啝垣太郎，高橋宏樹:水勾配が設けられた浴室林の勾配,すべ りの安全性からみた評価に関する研究 歩行の場合の評価指標の提示,日本建 築学会構造系論文集,第459号,pp.31 39,1994年5月
2)横山 裕,稻坦太郎,高橋宏樹,小野英哲:高踰者の安全性からみたすべりの評価 に関する基礎的研究 その 2 歩行メカニズムの高踰化にともなうすべりの 評価の変化の傾向,日本建築学会大会学術講演梗概集A-1,pp.641 642,1995 年8月

3)横山 裕,小野英哲,榴垣太郎,高梪宏樹:高路化にともなう歩行メカニズムの変 化からみたすべりの評価の相対的変化の推定 高略者の安全性からみた床の すべりの評価に関する基礎的研究 その 1 ,日本建筑学会構造系論文集,第478 号,pp.35 44,1995年12月

4)横山裕，小野英梊，稆垣太郎，高橋宏樹:水勾配が設けられた浴室床等の勾配，す ベりの安全性からみた評価に関する研究 浴槽出入の場合の評価指標の提示, 日本建筑学会構造系論文集,第466号,pp.31 39,1994年12月

5)小野英哲,高橋宏樹,泉 譲太,高橋成明:高跲者の安全性からみた床および斜路 のすべりの評価方法, 日本建築学会構造系論文集,第484号,pp.21〜29,1996年 6 月

6)小野英哲,上野静二,横山 裕,大野隆造,三上貫正:安全性からみた浴室床および 浴槽底のすべりの評価方法に関する研究 その 1 すべり抵抗の测定方法の 設定および浴槽縁断面寸法の設定,日本建築学会構造系論文報告集,第384号, pp. 26 33,1988年2月

7)J.P.Guilford著,秋重義治監訳:精神测定法,培風館,1969年

(1996年 9 月 9 日原稿受理，1997年 3 月 26 日採用決定） 